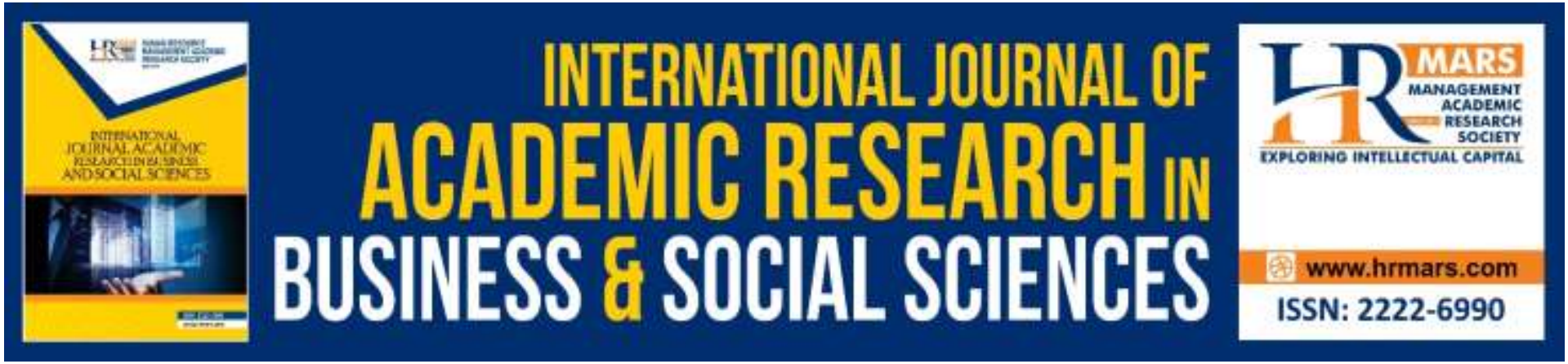

\title{
Analysis of Comparative Advantages and Export Determinants of Indonesian Tuna Fish
}

Fauzian Akmal Ramli, Rossanto Dwi Handoyo, Abdul Rahim Ridzuan, Mohamad Idham Md Razak

To Link this Article: http://dx.doi.org/10.6007/IJARBSS/v10-i5/7207

DOI:10.6007/IJARBSS/v10-i5/7207

Received: 12 March 2020, Revised: 20 April 2020, Accepted: 29 April 2020

Published Online: 17 May 2020

In-Text Citation: (Ramli et al., 2020)

To Cite this Article: Ramli, F. A., Handoyo, R. D. A. R. R., \& Razak, M. I. M. (2020). Analysis of Comparative Advantages and Export Determinants of Indonesian Tuna Fish. International Journal of Academic Research in Business and Social Sciences, 10(5), 361-371.

Copyright: () 2020 The Author(s)

Published by Human Resource Management Academic Research Society (www.hrmars.com)

This article is published under the Creative Commons Attribution (CC BY 4.0) license. Anyone may reproduce, distribute, translate and create derivative works of this article (for both commercial and non-commercial purposes), subject to full attribution to the original publication and authors. The full terms of this license may be seen

at: http://creativecommons.org/licences/by/4.0/legalcode

Vol. 10, No. 5, 2020, Pg. 361 - 371

http://hrmars.com/index.php/pages/detail/IJARBSS

JOURNAL HOMEPAGE

Full Terms \& Conditions of access and use can be found at http://hrmars.com/index.php/pages/detail/publication-ethics 


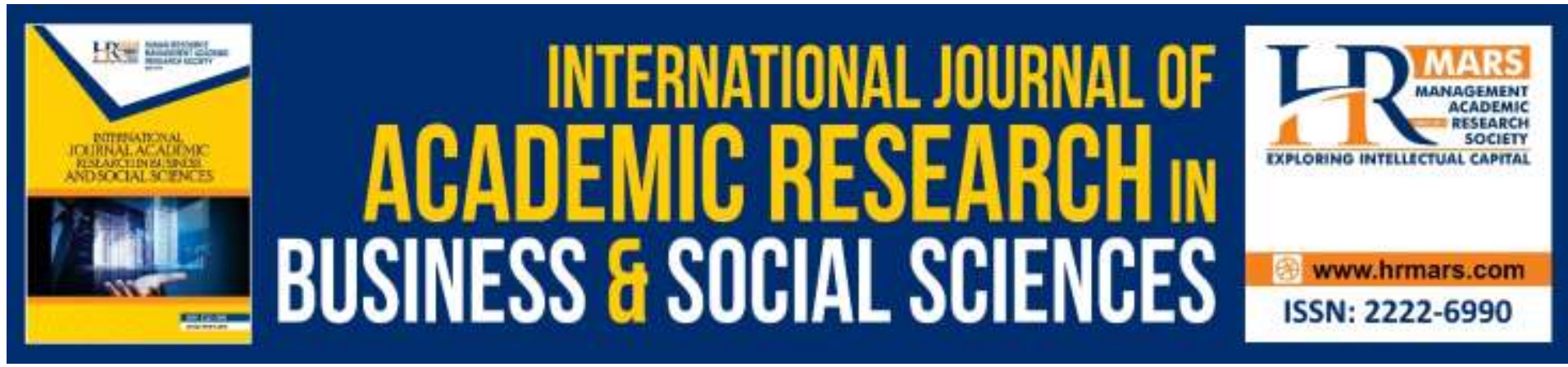

\title{
Analysis of Comparative Advantages and Export Determinants of Indonesian Tuna Fish
}

\author{
Fauzian Akmal Ramli \\ Faculty of Economics and Business, Universitas Airlangga \\ Email: fauzian.akmal.ramli-2014@feb.unair.ac.id. \\ Rossanto Dwi Handoyo \\ Faculty of Economics and Business, Universitas Airlangga, Indonesia \\ Email: Rossanto_dh@feb.unair.ac.id
}

\begin{abstract}
Abdul Rahim Ridzuan, Mohamad Idham Md Razak
Faculty of Business and Management, Universiti Teknologi MARA, Melaka Campus, Malaysia Email: Rahim670@staf.uitm.edu.my, iedham@warga.uitm.edu.my
\end{abstract}

\begin{abstract}
Indonesia is a maritime country that has a considerable fisheries potency and has become one of the largest tuna exporters in the world. This study aims to determine the competitiveness and analyze the determinants of Indonesian tuna export to importing countries (Japan, United States, and Thailand) in 2001-2016. Relative Revealed Comparative Trade Advantage (RTA) index was used to measure competitiveness. Gravity model and panel regression were used as the basis for selecting the variables and analysis of its determinants. The results of the RTA index indicate that Indonesia has a great comparative advantage or positive index value in all three main markets of Indonesian tuna products. The Panel data regression results show that real GDP of the importing country, Indonesian real GDP, real exchange rate, and RTA index have a positive and significant effect on the export of tuna fish, whereas distance variable performs negative effect.
\end{abstract}

Keyword: Tuna Export, Relative Revealed Comparative Trade Advantage (RTA), Gravity Mode

\section{Introduction}

Indonesia is the largest archipelagic country in the world. Currently, Indonesia is putting a severe effort in following the Djuanda Declaration in the United Nations Convention on the Law of the Sea (UNCLOS). As a result, the world has recognized the sea territories of Indonesia, including the surrounding sea, which is located between and within the Indonesian archipelago to the unified area of Indonesia as the legal convention UNCLOS international sea. It was also approved by the UN General Assembly on April $30^{\text {th }}, 1982$. Marine or maritime aspects can be a major theme in national development, especially in the utilization of marine potential to prosper Indonesian society. The fisheries industries have contributed about 2 
percent over decades for the Indonesian economy. This sector encourages the growth of agro-industry through the provision of raw materials, increasing the country's foreign exchange through fishery product exports, providing employment, increasing farmers' income, and contributing to the increase in Gross Domestic Product (GDP).

Figure 1: Indonesian Export Value of Tuna Fish by Major Destination Countries, 2002-2015

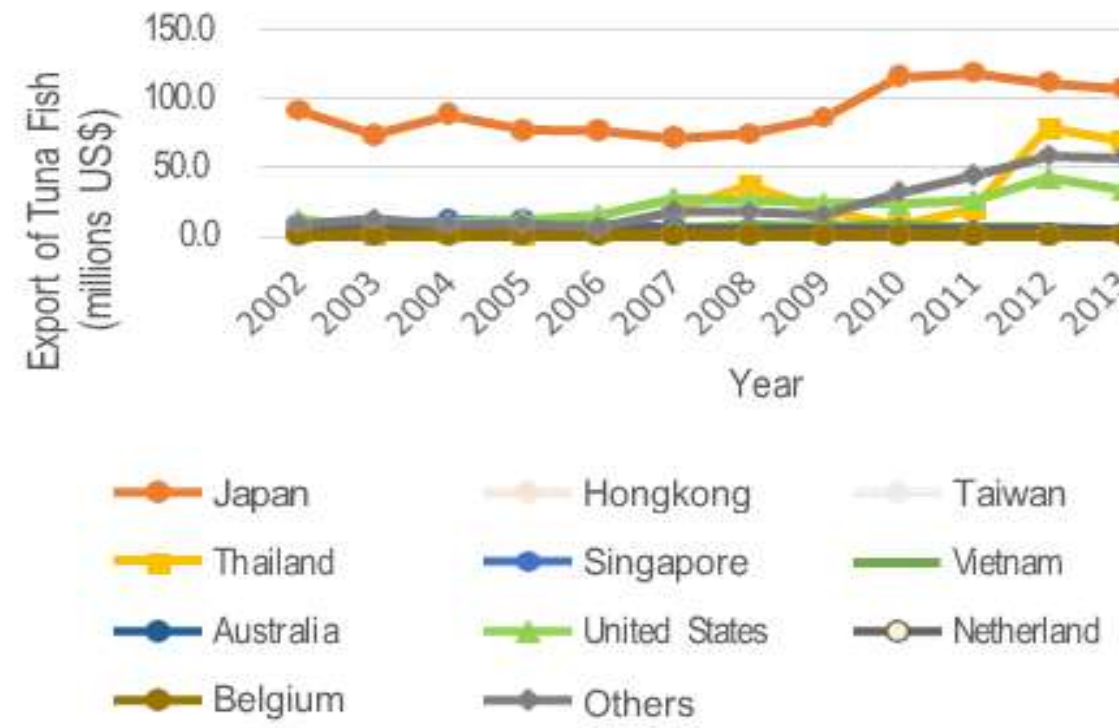

Source: Indonesian Central Bureau of Statistics (2017)

In 2016, Indonesia became the second largest tuna supplier in the world, or around 16 percent of tuna in the world. Based on Figure 1, Indonesian tuna exports are mostly focused on three countries, namely Japan, Thailand, and the United States. The value of tuna fish exports in these three countries reaches around $68 \%$ of the total value of Indonesian tuna fish exports in 2015. Japan is the main exporter for Indonesian tuna fish exports, with an average value of USD 87 million annually, followed by Thailand, worth of USD 27 million and The American Unions, reaching USD 20 million. Also, Singapore, Vietnam, Hong Kong, Taiwan, Australia, the Netherlands, and Belgium, are among the top ten exporters for Indonesian tuna products, and collectively contribute USD 700 thousand to USD 5 million every year. In general, the value of Indonesian tuna exports (fresh, frozen, processed) from year to year has been fluctuating. Since 2012, a decline in exports was noticed, compounded by the enactment of a transshipment ban in 2015 by the Ministry of Maritime Affairs and Fisheries. As a result, tuna catches records have been consistently below the allowable tuna catch quota. 
In terms of international economics, discussions about competitiveness and comparative advantage have been enormous (Laursen, 2015; Qinetti et al., 2009). Krugman (1996) states that a country's economic success depends on its international competitiveness and it has become a concern for business, political, and educated actors. In international trade, each country always strives to maintain a higher competitiveness than other countries to ensure that their products can easily penetrate the international market. Most researchers support the concept of competitiveness and competitiveness of countries, such as Mulatu (2016) who argues that the idea of competitiveness is not only useful but also part of a country's development strategy. International competitiveness is a welfare creation in the context of international economic interaction. It is not only related to the productivity or efficiency of a company, but it cares about the efficiency of high-value sectors that will improve the overall performance of the national economy.

Based on this background, this study attempts to examine the comparative advantage of Indonesian tuna fish exports, measured by the Relative Revealed Comparative Trade Advantage (RTA) index. Also, this study aims to analyze the determinants that affect Indonesian tuna fish exports with the three main trade partner countries, namely Japan, the United States, and Thailand. The results of this study are expected to act as the input for the business actors and the government in efforts to increase Indonesian tuna exports.

\section{Research Method \\ Data Specification}

For the analysis of comparative advantage, the calculation of the RTA index requires the data of the import and export value of international trade and tuna. For the determinant analysis, this study uses secondary data in the form of a panel data consisting of cross-section and time-series data. The study used the Time series data, which is the annual data from 2001 to 2016 and crosssection data of the three main export destination countries. The tuna fish data used in this study are fresh, frozen, and packaged with the HS code of 0302.30, 0303.40, and 1604.14 respectively. The variable retrieval is based on the gravity model with the addition of exchange rate variables and competitiveness index, as used in several previous studies (Rahmah 2016; Natale, 2015; Bilas et al., 2015; Yuniarti, 2007). The dependent variable in this study includes Indonesian tuna exports (EV). For the independent variables: importer's real GDP (RGDPj), Indonesia's real GDP (RGDPi), real exchange rate (RER), Distance (R), Relative Revealed Comparative Trade Advantage (RTA) Index were employed. The required data in this study were sourced from the Trademap International Trade Center, the World Bank, and GeoDataSource. 
INTERNATIONAL JOURNAL OF ACADEMIC RESEARCH IN BUSINESS AND SOCIAL SCIENCES

Vol. 10, No. 5, May, 2020, E-ISSN: 2222-6990 @ 2020 HRMARS

Table 1. Types and Data Sources

\begin{tabular}{lcl}
\hline \multicolumn{1}{c}{ Data } & Unit & \multicolumn{1}{c}{ Source } \\
\hline Tuna Export & USD & $\begin{array}{l}\text { International Trade } \\
\text { Centre Trademap } \\
\text { World Bank }\end{array}$ \\
$\begin{array}{l}\text { Real GDP } \\
\begin{array}{l}\text { Real exchange } \\
\text { rate }\end{array}\end{array}$ & USD & World Bank \\
Distance & Kilometer & GeoDataSource
\end{tabular}

To measure competitiveness, the Relative Revealed Comparative Trade Advantage (RTA) index was used. RTA index is decomposed by combining the Revealed Comparative Advantage (RCA) index and the Revealed Comparative Disadvantage (RCDA) index.

$R C A_{I J}=\left[\frac{X_{i j} / X_{j}}{X_{i w} / X_{w}}-1\right] \times 100$

where:

RCAij: RCA value for tuna fish commodities Indonesia

Xij: The export value of Indonesian tuna fish commodities to importing countries

$\mathrm{Xj}$ : The total value of Indonesian exports to Indonesian tuna fish importing countries

Xiw: The value of the export of world tuna fish commodities to the Indonesian tuna fish importing country

$X w$ : The total value of world exports to Indonesian tuna fish importing countries

The RCA $>0$ value states that the country has a comparative advantage or strong competitiveness in a product. If the RCA value is value $<0$, the country does not have a comparative advantage in a product (Isogai, Morishita, \& Ruffer, 2002).

RCA analysis was used to see the comparative advantage of a product. This analysis explains if the proportion of exports of a type of goods to total exports by a country is higher than the share of the same export of goods in the world. This signifies that the country has a comparative advantage in the goods. If RCA assesses competitiveness in terms of exports, the RCDA index assesses competitiveness from the import side. By knowing the structure of imports of a country, comparative disadvantages can be known. This index is computed as follows:

$R C D A_{I J}=\left[\frac{M_{i j} / M_{j}}{M_{i w} / M_{w}}-1\right] \times 100$

Where:

RCDAij: RCDA value for Indonesian tuna fish commodities

Mij: Import value of Indonesian tuna fish commodities from tuna importing countries 
Mj: Indonesia's total import value from Indonesian tuna fish importing countries

Miw: Import value of world tuna fish commodity from Indonesian tuna importing country

Mw: Value of total world imports from Indonesian tuna fish importing countries

RCDA values that are less than 0 mean that a country has a comparative advantage over the product, whereas if the RCDA value is more than 0 , it indicates that a country has a comparative disadvantage in the product.

After the two indices are calculated, the RTA index can be computed using the following formula: RTAij = RCAij - RCDAij

The RTA index provides a comprehensive calculation of comparative advantage by combining the import and export sides of trade relations between countries. If the RTA show positive values, they signify comparative advantage, while negative values indicate comparative disadvantages.

\section{Results and Discussion}

\section{Analysis of the Comparative Advantages of Indonesian Tuna}

In this study, the competitiveness of tuna fish products can be reflected in the Relative Revealed Comparative Trade Advantage (RTA) Index. Figure 2 shows the value of the RTA for the export of Indonesian tuna fish products to the three main destination countries in 2001 and 2016 in the quadrant. The results obtained in the three destination countries showed an interesting varied results.

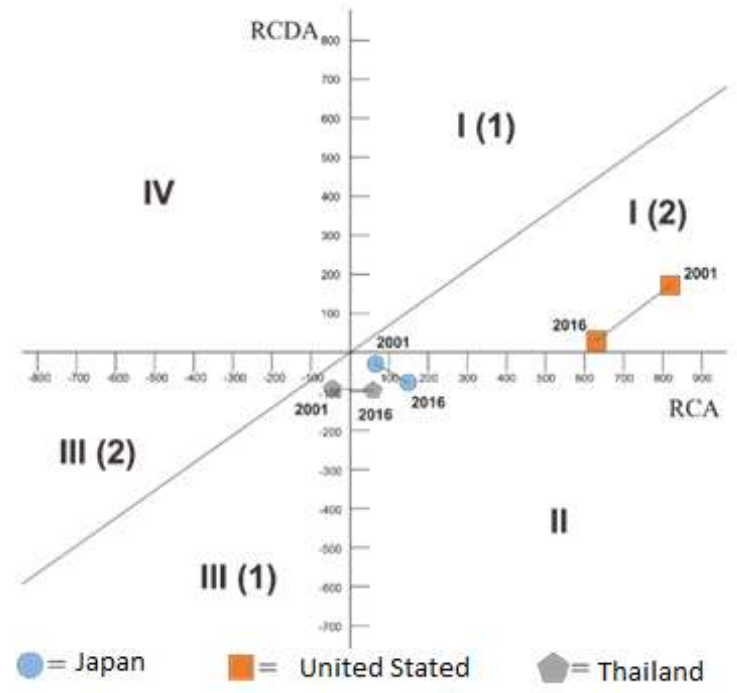

Source: Author's Calculation

\section{Figure 2 Position of Competitiveness (RTA index) of Indonesian Tuna Fish Export Products with Japan, the United States, and Thailand}

The highest RTA index value is located in the United States market, both at the beginning of the 2001 period until the end of 2016. The position of the RTA distribution point for Indonesian tuna fish products remains in the first quadrant (2) throughout the study period, reflecting a positive RTA value due to a greater positive RCA value than the positive value of RCDA. This position was followed by the location of the point farthest from the diagonal compared to the markets of 
Japan and Thailand, which reached the index value of 648.20 in 2001 , but declined and closer to the diagonal line in 2016 with an index value of 598.93.

This result is justifiable because the largest consumer of canned tuna in the World is the United States and to fulfill the demand, the United States must import tuna from other countries, including Indonesia. Moreover, the United States has imposed exemption from export duties based on the Generalized System of Preference (GSP) for developing countries, especially Indonesia, from 5-15 percent to 0 percent for fishery products in 2015.

Nonetheless, the implementation of the GSP was followed by a tightening of the standard in 2016 and the value of the RTA index experienced a decline, which means reduced competitiveness of tuna fish products in the United States. This situation is exacerbated by cases of bacterial content in Indonesian tuna products that hamper and reduce the position of competitiveness of Indonesian tuna products.

In the Japanese market, the shift that occurred from 2001 to 2016 showed an increase in competitiveness, as seen from the point of RTA for Indonesian tuna fish products in Japan which increasingly moved away from the diagonal line. This situation was due to the increasing value of the RTA index from 97.06 to 250.46 at the end of the period. The position of the RTA distribution point for Indonesian tuna fish products in Japan in quadrant II reflects the most favorable position for Indonesia because this shows that Indonesian tuna fish products have a comparative advantage in terms of both exports and imports of Japan.

For the Thailand market, the distribution of RTA points for Indonesian tuna products is in quadrant III (1) in 2001, with numbers 56.66 and quadrant II in 2016 at 158.90. This result explains that Indonesian tuna fish products in Thailand have better competitiveness at the end of the period.

The increasing competitiveness for Indonesian tuna in Japan is inseparable as there is a high demand for fresh tuna among the Japanese. Thailand is the largest canned tuna exporter and competitor for Indonesian tuna fish products. To meet the demand of the canned tuna production, Thailand needs a humongous source of raw materials both in the form of frozen and fresh tuna. Overall, the Thai canned tuna industry is still flourishing but facing an obstacle in procuring raw materials for the production of canned tuna. This has resulted in Indonesia's capability to penetrate to the Thai market through frozen and fresh tuna. Thus, the competitiveness of Indonesian tuna products in Thailand would continue to increase along with the increase in canned tuna production by Thailand.

The markets of the United States, Japan, and Thailand do open the room for opportunities but, at the same time, increase the challenge for tuna fish exporters, and appropriate efforts are needed to improve the competitiveness of Indonesian tuna in dynamic international trade.

\section{Determinants of Indonesian Tuna Fish Export}

This part attempts to analyze the determinants of the export of Indonesian tuna fish products to Japan, the United States, and Thailand (EVALijt). In this study, the independent variables used are Indonesian GDP (RGDPit), importer's GDP (RGDPjt), and distance (DISTijt), as well as variables of real (RERijt) exchange rates and Revealed Comparative Trade Advantage (RTAijt) indices which are thought to influence Indonesian tuna exports. The results obtained after passing the model selection test are the following Random Effect models: 
Table 2. Random Effect Model Regression Results

\begin{tabular}{lccc}
\hline \multicolumn{2}{c}{ Dependent Variable: InEV } & Coefficient & p-value \\
\hline & Cons & $-43,77836$ & 0,000 \\
\hline InRGDPj & 5,37589 & 0,000 \\
InRGDPi & 0,82390 & 0,012 \\
InRERij & 2,05582 & 0,000 \\
& InDist & $-15,54574$ & 0,000 \\
& RTA & 0,00099 & 0,054
\end{tabular}

Number of Observations

48

R-square

0,8460

Chi-square probability $\quad 0,000$

\section{Source: Authors' Calculation}

In the form of equation, it can be written as:

InEVijt $=-43,77836+5,37589$ InRGDPjt + 0,8239 InRGDPit + 2,05582 InRERijt -

15,54574 InDistijt + 0,00099 RTAijt + عij

The estimation results show the positive and significant effect of Indonesia's real GDP as an exporter on the export of Indonesian tuna fish products. This result agrees with hypotheses and is similar to various previous studies (Natale, Borrello, \& Motova, 2015; Yuniarti, 2007). Exporters' GDP reflects the country's production capabilities, and when the GDP of exporters increases, the country's production and export levels will also increase. Conversely, if the exporter's GDP falls, the country's production will also decline, and that exports by the country will decline.

For the real GDP of the importer or export destination, this study shows the same results as the real GDP of the exporter, which confirms with previous research (Natale et al., 2015; Rahmah, 2016; Yuniarti, 2007). For importing countries, GDP represents the absorption capacity or the ability of a country to consume goods from other countries. An increase in the importers' GDP (Japan, the United States, and Thailand) will also increase the imports for fishery products. Vice versa, if the importer's GDP has decreased, the purchasing power of the country will also decrease.

The real exchange rate of Rupiah against the currency of the importing country is known to have a negative relationship on Indonesian tuna exports. If the real exchange rate of a country appreciates, then the price of foreign goods will be relatively lower, and domestic goods will 
relatively become more expensive. On the contrary, if the real exchange rate of a country is depreciated, then foreign goods will be more expensive and domestic goods will be cheaper. The unidirectional relationship between the exchange rate of the Rupiah and the currency of the importing country is consistent with the research conducted by Rahmah (2016). When the Rupiah depreciates, the price of Indonesian tuna fish products will become more competitive for the tuna fish market in the importing country and foreign consumers can consume more Indonesian tuna products. The opposite is also true if the rupiah appreciates, which causes Indonesian tuna products to be relatively more expensive and become less competitive for overseas markets and foreign consumers will consume fewer Indonesian tuna products than before.

Distance has a negative influence on the export of Indonesian tuna fish products. The results are in line with the results of research conducted by Yuniarti (2007), Natale et al. (2015). The negative influence of distance to Indonesian tuna exports is a proxy of transportation costs that hamper international trade activities. The farther the distance of destination country, the greater the transportation costs produced. Costs incurred due to distance between regions can increase the price of goods traded.

Other obstacles caused by distance include the durability of the product. It is known that there are three types of tuna products, fresh tuna, frozen tuna, and canned tuna. The influence of distance can be seen in the United States as one of the main importers of Indonesian tuna fish products as the United States import more canned tuna than other types of tuna products. In contrast, the main importing countries that are closer, namely Japan and Thailand, prefer to import fresh-type tuna products - and frozen in addition to the country's consumer preferences. This situation is caused by fresh tuna is a highly perishable food that has short shelf life and the quality will decrease rapidly if it is not handled properly and appropriately.

The RTA index results show that the coefficient is as expected. It has a positive and significant effect on the export of Indonesian tuna fish products. This result is similar to the research by (Bilas et al., 2015), which states that comparative advantage has a positive relationship with exports produced by a country. This situation shows that the greater the competitiveness or when lower opportunity cost is needed to produce Indonesian tuna products, the greater the export of tuna products will be produced. Conversely, when competitiveness is lower, or any increase of opportunity cost is generated in producing Indonesian tuna products, the lower the export of tuna products will be produced.

\section{Conclusions and Suggestions}

Indonesia has a comparative advantage in tuna fish products in the three main export destination countries for tuna fish, which are the United States, Japan, and Thailand. Indonesian tuna fish products in the United States market recorded the highest value despite experiencing a decline at the end of the study period. In contrast to the Japanese and Thai markets, it experienced an increase at the end of the study period. Among the variables studied: the variable of the country's real GDP, the importer's real GDP, the exchange rate, and the RTA index has a positive and significant effect on tuna exports. In contrast, distance has a negative and significant impact on the export of Indonesian tuna fish products.

Based on the results obtained, these moves should be considered. Firstly, increasing exports and comparative advantage by maintaining exchange rate stability, as the exchange rate variable is 
quite influential for Indonesian tuna fish exports. Secondly, the government and business actors need to cooperate to maintain and improve the quality and standards, such as with strict temperature control and laboratory tests to increase durability and maintain the quality of tuna fish. Next, maintaining the diversification of products and markets to maintain and enhance competitiveness in a dynamic international trade environment. For example, developing markets to Middle Eastern countries whose consumption of fishery products begins to increase. In conclusion, tuna has great potential that still has a room to greater potential for Indonesia.

\section{References}

Bilas, V., Bošnjak, M., (2015). Revealed Comparative Advantage and Merchandise Exports: The Case of Merchandise Trade Between Croatia and the Rest of the European Union Member Countries, 29-48.

Bui, T. H. H., \& Chen, Q. (2017). An Analysis of Factors Influencing Rice Export in Vietnam Based on Gravity Model. Journal of the Knowledge Economy, 8(3), 830-844.

Dell'Ariccia, G. (1998). Exchange Rate Fluctuations and Trade Flows: Evidence from the European Union. IMF Working Paper.

Erkan, B., \& Saricoban, K. (2014). Comparative Analysis of the Competitiveness in the Export of Science-Based Goods Regarding Turkey and the EU+13 Countries. International Journal of Business and Social Science, 5(81), 117-130.

Evans, C. L. (2006). Border effects and the availability of domestic products abroad. Canadian Journal of Economics, 39(1), 211-246.

Head, K. (2003). Gravity for Beginners. Rethinking the Line: The Canada-U.S. Border Conference, (January), 1-11.

Isogai, T., Morishita, H., \& Ruffer, R. (2002). Analysis of Intra and Inter-Regional Trade in East Asia: Comparative Advantage Structures and Dynamic Interdependency in Trade Flows.

Kang, H., \& Fratianni, M. U. (2006). International Trade Efficiency, the Gravity Equation, and the Stochastic Frontier. SSRN Electronic Journal.

Kareem, F. O. (2013). Modeling and Estimation of Gravity Equation in the Presence of Zero Trade : A Validation of Hypotheses Using Africa's Trade Data. The 140th EAAE Seminar : Theories and Empirical Applications on Policy and Governance of Agri-Food Value Chains.

Krugman, P. R., \& Obstfeld, M. (2003). International Economics (Sixth Edition). Boston: Pearson Education, Inc.

Laursen, Keld. (2015). Revealed comparative advantage and the alternatives as measures of international specialization. Eurasian Business Review, 5(1), 99-115.

Mankiw, N. G. (2010). Macroeconomics (Seventh ed). Worth Publishers.

Natale, F., Borrello, A., \& Motova, A. (2015). Analysis of the determinants of international seafood trade using a gravity model. Marine Policy, 60(June), 98-106.

Qineti, Artan, Rajcaniova, Miroslava, \& Matejkova, Eva. (2009). The competitiveness and comparative advantage of the Slovak and the EU agri-food trade with Russia and Ukraine. Agricultural Economics, 55(8), 375-383.

Rahmah, K. N. (2016). Trade Flows Analysis and the role of standards on canned tuna trade. Bogor Agricultural University.

Salvatore, D. (2013). International Economics, 11th Edition. New Jersey: John Wiley \& Sons, Inc. 
INTERNATIONAL JOURNAL OF ACADEMIC RESEARCH IN BUSINESS AND SOCIAL SCIENCES

Vol. 10, No. 5, May, 2020, E-ISSN: 2222-6990 @ 2020 HRMARS

Yuniarti, D. (2007). Analysis of Indonesian Bilateral Trade Determinants of the Gravity Model Approach. Economic Journal of Emerging Markets, 12(2). 